\title{
Influx of Refugees and Transformations of Land Use: Case of the Borgop Land (Adamawa- Cameroon)
}

\author{
AOUDOU DOUA Sylvain ${ }^{1}$, NARKE Jean Cyrille ${ }^{2}$ \\ ${ }^{1}$ Higher Institute of Sahel (HIS), University of Maroua. P.O. box 46, Maroua, Cameroun \\ ${ }^{2}$ National Institute of Cartography (NIC), P.O. box 157, Yaoundé, Cameroon
}

\begin{abstract}
This study focused on the assessment of environmental changes caused by the influx of Central African refugees in the Borgop locality. The social context of this area marked by a population explosion following the installation of some 18,000 Central African refugees led to major environmental changes in general and, in particular, changes in the structure of the vegetation cover. The objective of this work was to analyze the qualitative and quantitative evolution of each type of land occupation between 1999 and 2014; In order to highlight the environmental transformations in the area. The remote sensing methods and techniques associated with the fieldwork first allowed to identify the different types of land use in the area and to show their present state; and in a second stage we have highlighted their evolution between 1999 and 2014. The results show that the influx of refugees has spurred unprecedented pressure on vegetation through increasing demand for firewood, extending crop areas, intensifying bushfire, degradation of pastures, and destruction of galleries and light forests for lumber and service needs. In addition, the installation of Central African refugees in Borgop, a locality on the outskirts of the Mbéré Valley National Park, has a negative impact on this protected area and its resources.
\end{abstract}

Keywords: Refugees, transformations of land use, Borgop

\section{Introduction}

According to the UNHCR (2012), since 2011, tens of millions of people that is 33.9 million are particularly vulnerable. Most are vulnerable to armed conflict and political violence within their communities or countries of origin: civilians caught in conflict, refugees, asylum-seekers, long-term refugees and internally displaced persons within their country. This situation brings individuals, families and even whole communities to forced migration (Laliberté, 2007). For Cambrezy (2007), apart from the insecurity and export of conflict across borders, the influx of refugees more often feared the worst in terms of environmental degradation (access to fuelwood, Water, etc.). The environmental degradation caused by the influx of refugees is also of concern to the international community. Since the 1992 Rio Summit on Environment and Development, concerns about the negative impact of refugees on the environment have been taken very seriously. As a result, the Office of the United Nations High Commissioner for Refugees (UNHCR) has begun to integrate environmental issues into the planning of refugee assistance programs.

Indeed, the waves of displacement of refugees are causing a huge increase in pressures on the environment and its resources. According to Black et al. (1996), the influx of refugees into a given area results in three types of potential environmental changes (transformations): changes in flora and fauna, soil degradation, and quality and quantity of water resources.

Thus, the series of armed conflicts that the CAR has witnessed since the takeover of power of Bozizé in CAR in 2003, several Cameroonian localities located at the border have known the arrival and massive installation of thousands of Central African refugees. In the Adamaoua Region, these are mainly the localities of Ngaoui, Borgop and Ngam. These refugees are welcomed in Ngaoui for the census at UNHCR focal points; From there, they are transported for the purpose of their settlement in the camp of Borgop. For the effective management of refugee numbers, Ngam Secondary Camp was established. Also, the Borgop land (Figure 1) located in the Adamaoua region, more precisely in the Department of Mbéré, Djohong District, has seen the succession of several waves of refugees (PUI, 2015). With a population of about 1000 inhabitants, this land is marked by a strong population growth following the arrival and then the massive installation of approximately 18000 Central African refugees in this zone; Resulting in unprecedented degradation of the environment and its resources. This study highlights the environmental changes following the massive arrival of refugees in the Borgop locality. These include changes in land use with attention to vegetation cover. Knowing that from time immemorial, man has moved to places that are more fortunate for his survival when nature becomes too restrictive (Gonim and Al, 2002). The destruction or long-lasting degradation of the biophysical environment in general and the vegetation cover in particular can negatively influence the populations living in the land and consequently lead them to migrate to a suitable site; The degradation of the resources of the Borgop land can also increase the anthropic pressure on the resources of the Mbéré Valley National Park. It is therefore important to carry out this study in order to maintain the balance between the number of inhabitants and the possibilities of the environment 


\section{International Journal of Science and Research (IJSR) \\ ISSN (Online): 2319-7064}

Index Copernicus Value (2015): 78.96 | Impact Factor (2015): 6.391

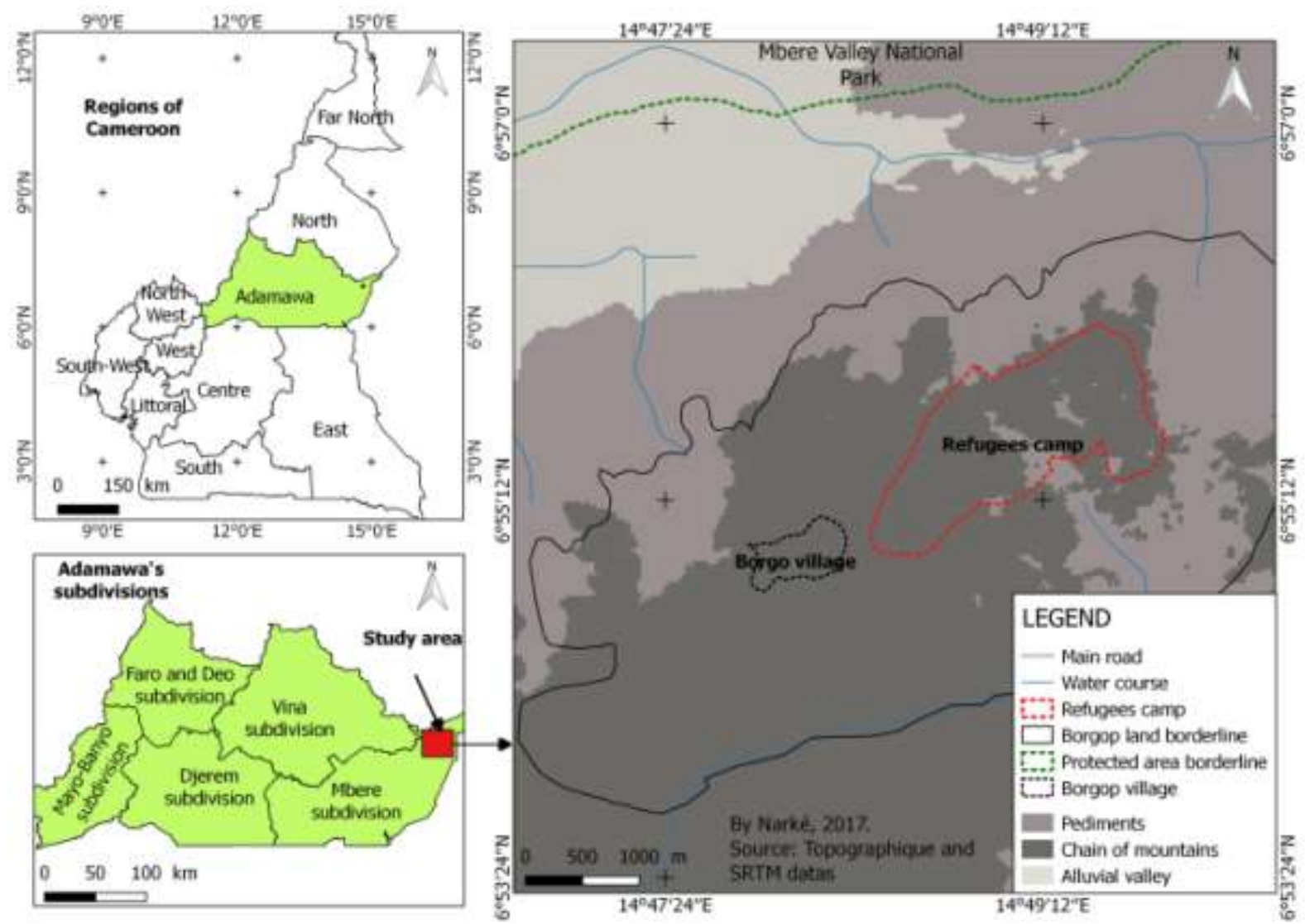

Figure 1: Location of the study area

\section{Materials and Methods}

\subsection{The study area}

The Borgop land (Figure 1), is located on the outskirts of the National Park of the Mbéré Valley; It is located at an altitude of $1300 \mathrm{~m}$ between latitude $06^{\circ} 90$ 'and $06^{\circ} 95^{\prime}$ and longitude $14^{\circ} 78$ 'and $14^{\circ} 83^{\prime}$; It is located in the Adamawa region, specifically in the Department of Mbéré, Djohong District. It is limited to the North by the National Park of the valley of Mberé (protected area of fauna); to the east by the land of Batoua, to the west by the soil of Nabémo and to the South it marks the limit between the Djohong and Ngaoui municipalities. The relief is not very rugged and has some peaks. This land has a humid tropical climate of altitude characterized by two seasons of unequal importance; A short dry season that runs from November to April and a long rainy season the rest of the year. Annual precipitation ranges from 1000 to $1300 \mathrm{~mm}$ / year. Vegetation formation is the Sudano-Guinean savannah of altitude (DFAP / MINEF, 2000). Many small streams cross the soil and flow into the Mbéré, which is the main river. Borgop owes its name to the river eponymous tributary of Mbéré. It was in 1953 with the creation of the national road that the population of the present village of Borgop will leave the valley to rejoin the road under the request of the Cameroonian state at the same period.

The population consists mainly of Gbayas, they are indigenous and practice hunting, fishing and agriculture; The Gbayas share the land of Borgop with the Mbororos, a people whose main activity is breeding, and the Mberes whose habits are close to those of the Gbayas. In addition to nearly 18,000 Central African refugees settled in the Borgop land (UNHCR, 2013), the indigenous population is estimated at about 1500 souls (BUCREP, 2005).

\subsection{Data, tools and methods}

\subsubsection{Methodological approach}

To highlight the environmental transformations in this area, we used the methods and techniques of remote sensing associated with field work; This allowed us to characterize the different types of land use and to establish the land use map of the area. The processing of the 1999 and 2014 satellite data associated with the fieldwork favored the qualitative and quantitative analysis of each type of land use between 1999 and 2014 .

\subsubsection{Data}

For this work we used three data sources. These were field surveys that helped identify land-use patterns (Figure 2 and 3 ); Satellite images to show the dynamics of the different types of land use between 1999 and 2014; Socio-economic surveys to identify and describe the processes and factors of observed spatial dynamics.

\section{a) Field and socio-economic surveys}

The field surveys cover all the individual surveys of the different types of occupation of the study area. Each survey corresponds to a specific type of occupancy of space. These data have facilitated the identification of environmental changes in the Borgop land.

\section{Volume 6 Issue 7, July 2017 www.ijsr.net}




\section{International Journal of Science and Research (IJSR) \\ ISSN (Online): 2319-7064}

Index Copernicus Value (2015): 78.96 | Impact Factor (2015): 6.391

\section{b) The image data}

The image data cover all the satellite images used for the mapping of land cover types and the identification of the successive states of each type of land use for each of the selected dates. The processing of the image data enabled us to show the current state of land use and to reconstruct the dynamics of each type of soil occupation of the Borgop land between 1999 and 2014. The landsat 7 ETM + scenes of March 1999 made it possible to see the state of the occupation of the ground before the installation of the Central African refugees in the zone, and of two landsat 8 OLI scenes of February 2014 of coordinates (183/55 and 184 / 55) which made it possible to see the situation 4 years after the arrival of the refugees.

\subsubsection{Data processing and analysis}

The processing of these data was organized in three phases: pre-processing operations, numerical classifications and evidence of changes in land use.

\section{a) Pre-treatment operations}

This stage consisted in identifying the tools allowing us to identify and to highlight the types of soil occupation and then to represent them in classes. In order to be able to read the images and to decide the different classes of land use, we used two types of approach, namely the analogue approach (visual interpretation of image data facilitated by the correlation between the spectral signature of terrestrial objects and our knowledge Of the terrain) and the numerical approach (on the matching of the radiometric information contained in the satellite image with the information obtained from observations and field surveys). The definition and categorization of land-use classes is based on the correlation between the spectral signature of terrestrial objects and our knowledge of the terrain (Aoudou, 2010). Using this method, we have distinguished: gallery forests, light forests, wooded savannahs, wooded savannahs, shrub savannas, grassland savannahs and / or floodplain meadows, fields and fallow land, water and burnt soil, bare soil and sand heaps.

\section{b) Supervised classification of images}

In order to identify and individualize land occupancy classes with very similar spectral signatures, we have projected the GPS points obtained from our field surveys on the Landsat image used for mapping the vegetation cover of our study area. These GPS points projected on the image allowed us to define the training plots and record the spectral signature of each of these plots before proceeding to the supervised classification. For these classifications we have chosen the maximum likelihood method.

\section{c) Post-treatments}

This phase enabled us to highlight changes in land use. Specifically, the different land-use classes obtained by classification were transformed into polygons under Envi 4.5 and then imported into QGis 2.18. These layers of information obtained are complemented by information extracted from exogenous data such as the road network and the localities. The queries and spatial analyzes are then carried out to answer specific questions related to the central question of research. Finally, the maps are produced.

\section{Results}

The results obtained from the treatment of the different data sources give an overview of the land cover conditions as well as the evolution of the land-use types of the study area.

\subsection{Soil occupancy states in 1999 and 2014}

The results of the classifications of the various images used allowed us to draw up the occupation status of the Borgop land for each of these dates, to quantify the occupation of the soil and to highlight the state of soil occupancy. Table 1 shows the evolution of land use classes in Borgop between 1999 and 2014.

Table 1: Area of land-use types in Borgop land in 1999 and 2014

\begin{tabular}{|c|c|c|c|c|}
\hline Types of land use & \multicolumn{2}{|c|}{1999} & \multicolumn{2}{c|}{2014} \\
\cline { 2 - 5 } & $\begin{array}{c}\text { Area } \\
\text { (Hectares) }\end{array}$ & Percentage & $\begin{array}{c}\text { Area } \\
\text { (Hectares) }\end{array}$ & Percentage \\
\hline Forests galleries & 5127,3 & 23,81 & 4059 & 18,85 \\
\hline Clear Forests & 5698,8 & 26,47 & 2303,1 & 10,70 \\
\hline Wooded Savannah & 1371,6 & 6,37 & 3650,4 & 16,95 \\
\hline Trees Savannahs & 8514,9 & 39,54 & 2203,2 & 10,23 \\
\hline Shrub savannah & 333 & 1,55 & 853,2 & 3,96 \\
\hline Grassland Savannah & 401,4 & 1,86 & 432,9 & 2,01 \\
\hline Bare soils & 59,4 & 0,28 & 8030,7 & 37,30 \\
\hline Water and Burns & 26,1 & 0,12 & 0 & 0,00 \\
\hline Total & 21532,5 & 100,00 & 21532,5 & 100,00 \\
\hline
\end{tabular}

The analysis of Table 1 confirms the hypothesis that population growth and the settlement of refugees in the Borgop land contributed to the regressive dynamics of the vegetation cover. Indeed, uncovered areas (bare floors) have expanded as they have increased from $0.28 \%$ occupancy of the total land area to $37.30 \%$ with a change of $37.02 \%$. Closed formations (galleries and light forests) have been diminished by $20.73 \%$. Intermediate formations consisting of wooded savannahs and wooded savannahs lost $18.26 \%$ of their spatial extent; their degradation facilitated the extension of open formations (savannahs shrubs and grass) by $02,57 \%$.

\section{a) The state of land occupation in $\mathbf{1 9 9 9}$}

From the examination of Table 1, it can be observed that for land use in 1999 (Figure 3), the dominant land use type is the savannah class with 8514.9 hectares, i.e $39.54 \%$ of the study area. It is followed by the clear forest which covers an area of 5698.8 hectares or $26.47 \%$ of the total area. The gallery forests come in third position and cover an area of 5127.3 hectares or $23.81 \%$ of the total area of the studied land. Then we have the wooded savannahs with an area of 1371.6 hectares or $6.37 \%$. Shrub savannahs (333 hectares) and grassland savannahs (401.4 hectares) occupy $03.41 \%$ of the total study area. Water and burning (26.1 hectares) and bare soils (59.4 hectares) occupy $0.40 \%$ of the area. Vegetation occupies $99,60 \%$ of the study area. 


\section{International Journal of Science and Research (IJSR) \\ ISSN (Online): 2319-7064}

Index Copernicus Value (2015): 78.96 | Impact Factor (2015): 6.391

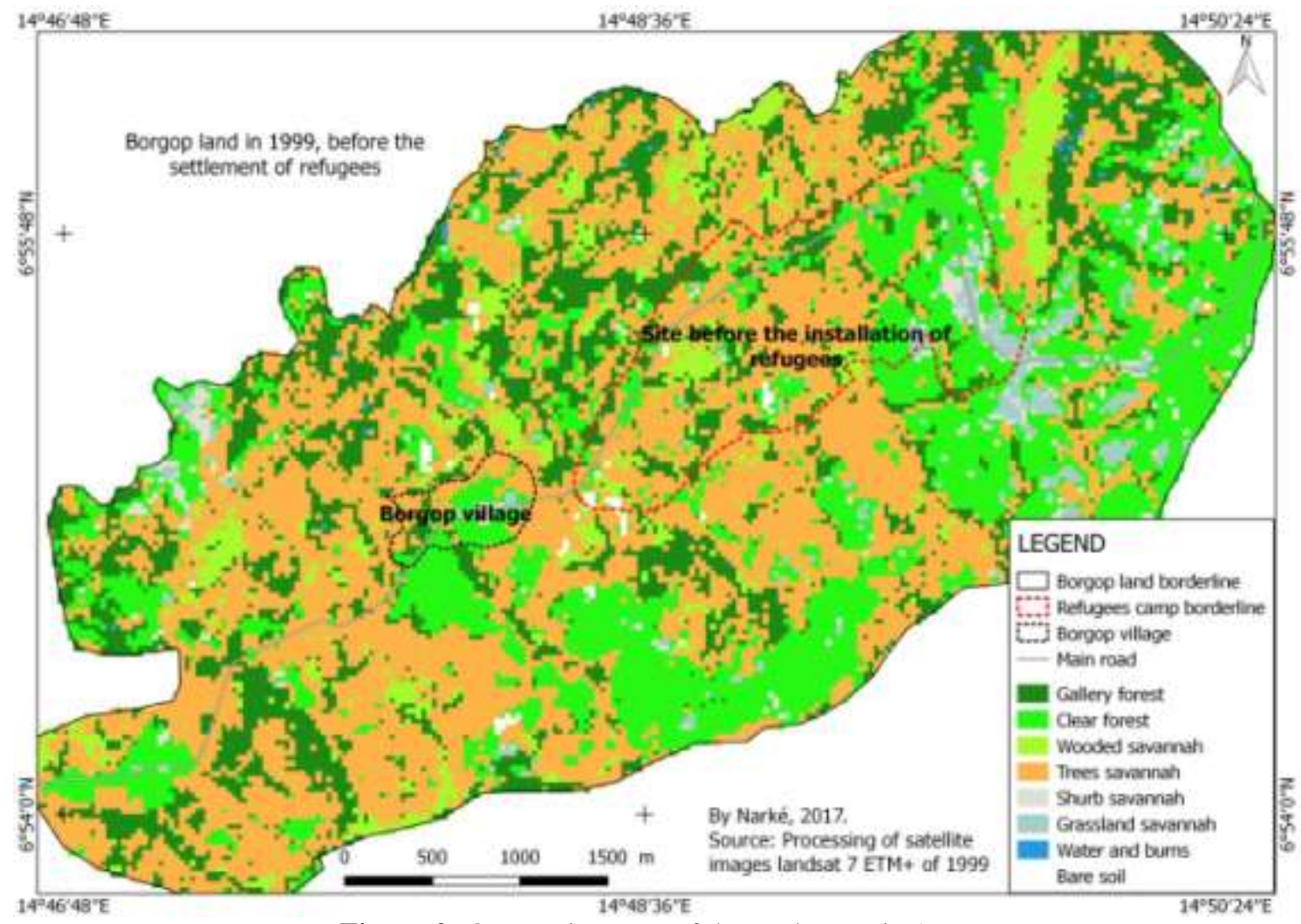

Figure 2: Occupation map of the study area in 1999

\section{b) The state of land use in 2014}

As regards land occupation in 2014 (Figure 3), the dominant land-use type is the bare soil class with an area of $8030.7 \%$ hectares, i.e $37.30 \%$ of the total area of the studied land. It is followed by the forest gallery which covers an area of 4059 hectares or $19.57 \%$ of the total area. The wooded savannahs come in third position and occupy an area of 3650.4 hectares, i.e $16.95 \%$ of the total area of Borgop land. Then we have the clear forest with an area of 2303.1 hectares or $10.70 \%$. The savannah trees occupy 2203.2 hectares or $10.23 \%$; they are followed by shrub savannahs $(853.2$ hectares) and grassland savannahs (432.9 hectares) or $05.97 \%$

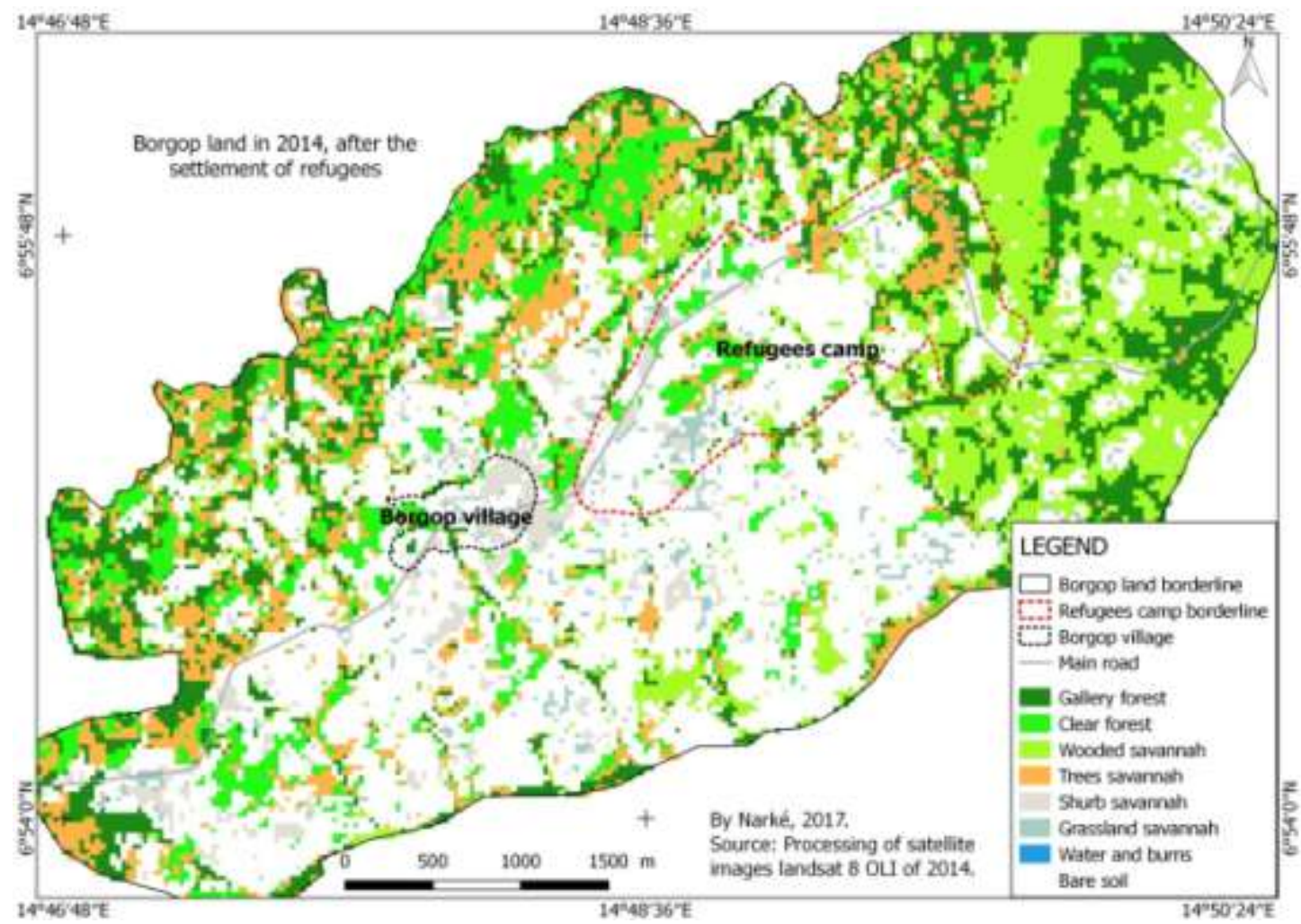

Figure 3: Occupation map of the study area in 2014

Volume 6 Issue 7, July 2017 www.ijsr.net 


\section{International Journal of Science and Research (IJSR) \\ ISSN (Online): 2319-7064}

Index Copernicus Value (2015): 78.96 | Impact Factor (2015): 6.391

\subsection{Evolution of the types of land occupation in Borgop between 1999 and 2014.}

The monitoring of the eight (8) classes of land use retained by the Landsat images of 1999 and 2014 enabled us to highlight the state of the spatial dynamics in this area. The crossing of the 1999 land use to that of 2014 allows us to detect some discernible variations in land-use classifications. Figure 4 shows the evolution of the land cover classes between 1999 and 2014. This figure shows an extension of the uncovered areas and a narrowing of the covered surfaces. Indeed, uncovered areas (bare soil) occupy $37.02 \%$ of the total area studied; Indicating the strong pressure exerted on the vegetation cover of this area. Between 1999 and 2014, vegetation cover was regressive. Forest formations (galleries and light forests) lost $20.73 \%$ of their spatial extent; the savannah trees lost $29.31 \%$ of their surface.

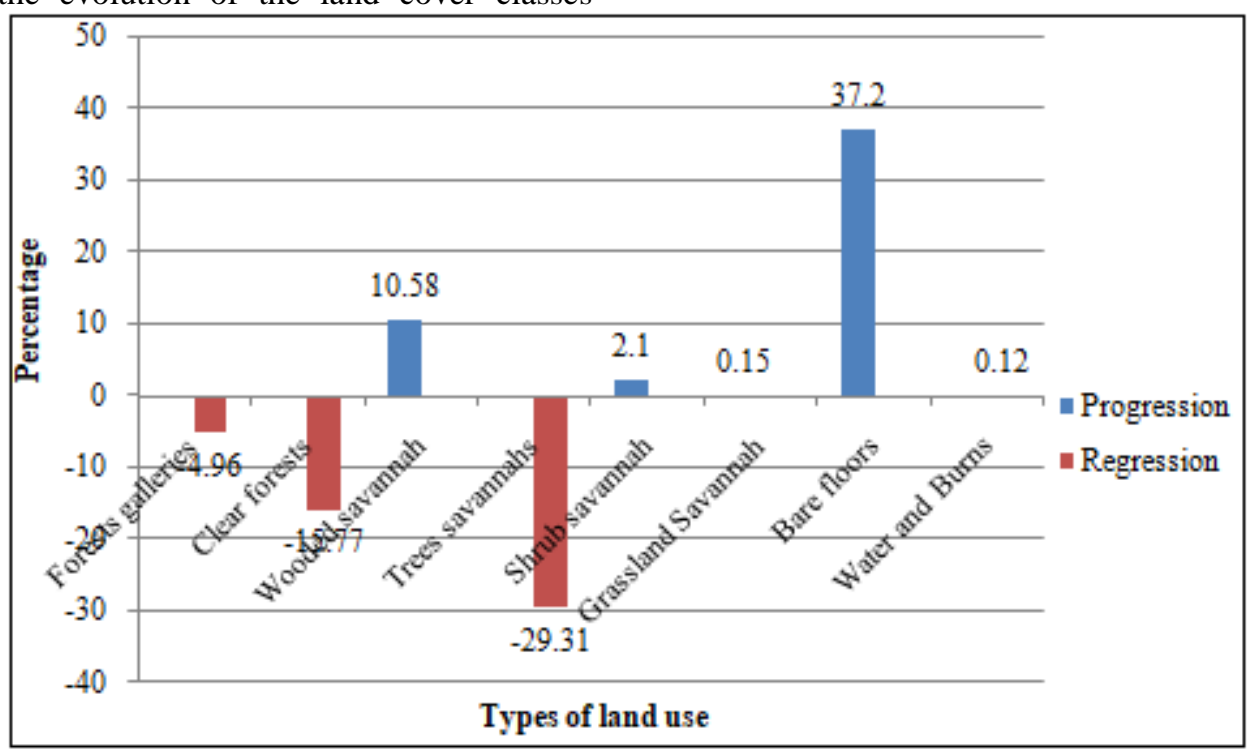

Figure 4: Evolution of the land-use classes in Borgop between 1999 and 2014 Source: images processing

\section{Interprétation}

The influx of Central African refugees resulted in an unprecedented occupation of space. This gave a regressive tendency to the general dynamics of the vegetation cover. The regressive evolution of the vegetation cover in the Borgop land is explained by the strong anthropic pressure exerted following the arrival and installation of nearly 18,000 Central African refugees in the area. For the arrival in 2014 of a new wave of refugees and the intensification of the troubles in the CAR has profoundly overturned this system. According to Souchaud (2002), the regressive evolution of the vegetation cover causes spatial and societal changes, migration upsets the relationship that villagers have with nature and permanently disrupts the environment. Piquouet (2002), points out that migration is no longer merely a factor in the regulation of "demographic surpluses", it is also a direct agent of transformations in systems of production, use of natural resources and ecosystems. It is an element that can be the cause or consequence of the evolution of the environments and in many cases of its degradation. And that, the increase in population implied an increased colonization of the environment (deforestation, cultivation of remote or poorly yielding lands), or migration.

In addition, the chronic poverty situation experienced by refugees and indigenous population favours the maintenance of demographic and land-based pressures on the environment. For the majority of refugees are totally dependent on humanitarian aid and need to gradually regain export activities to attract money in relatively landlocked areas and thereby improve their livelihoods. Thus, individually or as a group, refugees have developed activities such as the sale of firewood and timber, unsustainable collection of non-timber forest products (NTFPs); The consequences on the environment are visible, with regard to the increasingly aerated forest spaces around the large camps of refugees, as is the case of the Borgop land. This makes these refugees the culprits of the environmental degradation around the camps (Cambrézy, 2001). The environmental transformation driven by the various pressures exerted by these refugees is favored by the cuts of timber by the breeders for the construction of vast enclosures and the opening of vast fodder fields; The high use of uncontrolled bush fires by farmers, beekeepers and cattle breeders whose contribution to the regression of savannah formations is significant. Because transhumance in the CAR is no longer possible (insecurity too high), many floks have migrated to the east and other regions. Local livestock numbers have strongly increased with the arrival of Central African livestock, increasing pressure on agricultural land and agro-pastoral conflicts. There is also the exploitation of timber for the construction of houses and public works as well as the manufacture of art objects (mortars, bench and armor). There is then a strong extension of uncovered areas (bare soils) since any natural regeneration process is prevented by the ever increasing weight of these various anthropogenic pressures on plant resources in particular.

In addition, the marked decline in forest formations and tree savannahs can be explained by the strong anthropogenic pressure on agriculture, which remains the main source of income for the vast majority of the population (Narké,

Volume 6 Issue 7, July 2017 www.ijsr.net 


\section{International Journal of Science and Research (IJSR) \\ ISSN (Online): 2319-7064}

Index Copernicus Value (2015): 78.96 | Impact Factor (2015): 6.391

2015). Thus it is clear that the regression of the vegetation cover is much more important than its extension.

\section{Conclusion}

The influx of Central African refugees into the land has resulted in an abusive and uncontrolled exploitation of plant resources and, consequently, the degradation of vegetation cover due to the increased demand for firewood, which remains the main source of domestic energy for $95 \%$ of the population, extending crop areas, intensifying bushfire practices, degrading grazing lands, and destroying galleries and light forests for timber and service-wood which has become more pronounced with the proliferation of chainsaws.

However, it should be noted that the Borgop land is located on the periphery of a protected area (the Mbéré Valley National Park) and that it is significantly impacted by the influx of refugees into the area. Indigenous populations and refugees enter the area to carry out many of their activities (researching firewood and timber, researching grazing, conquering a new agricultural front ...), as the land is increasingly unable to meet needs.

Recognizing that humanitarian crises bring individuals, families and communities to migrate in order to ensure their survival; and that these crises and the resulting migration create situations of vulnerability in health (Laliberté, 2007). It is probably important, as Cambrezy (2007) puts it, to be interested in the concrete forms of vulnerability that affect refugees and displaced populations in the Borgop land and its various dismemberments. This is to anticipate potential opportunities for reaction to change.

\section{References}

[1] Aoudou Doua. S., 2010. Suivi de l'évolution de la végétation ligneuse de la savane soudanienne dans haute vallée de la Bénoué au Nord-Cameroun. Thèse de Doctorat, universté de Ngaoundére, 307p.

[2] PSEDD., 2003. Rapport de l'Enquête menée auprès des Communautés Bagyéli le long du tracé du pipeline : Partie Sud du Cameroun Bipindi - Kribi, 47p.

[3] Black, R., Sessaym., Milimounof, J., 1996. Les Réfugiés et les Changements écologiques. Le cas de la région forestière de Guinée, Londres, département de géographie, projet CFCE, rapport 2, King's College London, $41 \mathrm{p}$.

[4] BUCREP, 2005. Répertoire actualisé des villages du Cameroun : Troisième Recensement Général de la Population et de l'Habitat du Cameroun. Volume IV, Tome 07. 436p

[5] Cambrézy Luc, 2001. Réfugiés et exilés : Crise des sociétés, crise des territoires. Paris, Éditions des Archives contemporaines, 2001, 216 p.

[6] Cambrézy Luc, 2007. Réfugiés et migrants en Afrique : quel statut pour quelle vulnérabilité ? Revue européenne des migrations internationales, vol. 23 - n³, 2007, 16p.

[7] DFAP/ MINEF., 2000. Rapport des missions de prospection de l'équipe WWF/PSSN dans l'Adamaoua Camerounais, pour une contribution à l'élaboration d'une stratégie de conservation de la biodiversité :
Zones concernées: Tchabal Mbabo, Tchabal Gandaba, Vallée du Mbéré.

[8] Gonin Patrick et Véronique Lassailly-Jacob, 2002. Les réfugiés de l'environnement. Revue européenne des migrations internationales, vol. $18-\mathrm{n}^{\circ} 2,2002,20 \mathrm{p}$.

[9] Laliberté Danièle, 2007. Crises humanitaires, santé des réfugiés et des déplacés : un cadre analytique. Revue européenne des migrations internationales, vol. $23-\mathrm{n}^{\circ} 3$, 2007, 13p.

[10]MRC (Conseil Norvégien pour les Réfugiés), 2009. Rapport d'évaluation sur l'impact écologique des programmes de réfugiés. 66p.

[11] Narké J.C., 2015. Dynamique des paysages végétaux du Parc National de la Vallée du Mbéré et sa périphérie sud. Mémoire de Master II, Université de Ngaoundéré. $165 \mathrm{p}$.

[12] Picouet Michel, 2002. Formes de mobilité et dynamique de l'environnement en Tunisie. Revue européenne des migrations internationales, vol. $18-\mathrm{n}^{\circ} 2,2002,15 \mathrm{p}$.

[13] Première Urgence Internationale (PUI), 2015. Rapport d'évaluation de sécurités alimentaires et nutritionnelles et moyennes d'existence (SANME), Département du Mberé, Région de l'AdamaouaCameroun. 62p.

[14] Souchaud Sylvain, 2002. Migrations et mutations des systèmes agraires : la culture brésilienne du soja au Paraguay. Revue européenne des migrations internationales, vol. $18-\mathrm{n}^{\circ} 2,2002,27 \mathrm{p}$.

[15] Souchaud Sylvain, 2002. Migrations and mutations of agrarian systems: Brazilian soybean cultivation in Paraguay. European Journal of International Migration, vol. 18 - No. 2, 2002, 27p.

[16] UNHCR (Haut-Commissariat des Nations Unies pour les Réfugiés), 2012. Les réfugiés dans le monde : en quête de solidarité. $67 \mathrm{p}$.

[17] UNHCR (Haut-Commissariat des Nations Unies pour les Réfugiés), 2013. Rapport d'évaluation de l'assistance humanitaire et de la situation des réfugiés centrafricains vivant au Cameroun. 33p. 